\title{
ANALISIS KUALITAS PELAYANAN PERUSAHAAN DAERAH AIR MINUM (PDAM) TIRTA ALAMI KABUPATEN KEPAHIANG
}

\author{
Arminsyah \\ Program Studi Manajemen \\ Fakultas Ekonomi Universitas Dehasen Bengkulu \\ Merri Anitasari \\ Dosen Fakultas Ekonomi Universitas Bengkulu
}

\begin{abstract}
ABSTRAK
Arminsyah, Merri Anitasari; Analisis Kualitas Pelayanan Perusahaan Daerah Air Minum (PDAM) Tirta Alami Kabupaten Kepahiang. Penelitian ini bertujuan untuk mengetahui kualitas pelayanan Perusahaan Daerah Air Minum (PDAM) Tirta Alami Kabupaten Kepahiang. Sedangkan metode pengumpulan data yang digunakan penulis adalah kuesioner dengan menggunakan teknik analisis data berupa analisis kuantitatif yaitu analisis yang digunakan menyangkut pengolahan data dengan menggunakan rumus nilai rata-rata tertimbang dengan menggunakan keputusan Men.Pan Nomor KEP/25/M.PAN/2/2004 dalam 14 unsur pelayanan yang dikaji. Dari penyebaran kuesioner, maka didapat nilai rata-rata per unsur pelayanan yang paling tinggi adalah pada kemudahan persyaratan pelayanan yang diberikan oleh PDAM Tirta Alami Kabupaten Kepahiang yaitu dengan nilai unsur pelayanan sebesar 3,03. Sedangkan nilai rata-rata per unsur pelayanan yang paling rendah yaitu pada keadilan mendapatkan pelayanan sebesar 2,95. Nilai IKM pada PDAM Tirta Alami Kabupaten Kepahiang sebesar 63 yang berarti bahwa kinerja unit pelayanan pada PDAM Tirta Alami Kabupaten Kepahiang "baik" karena nilai tersebut berada diantara 62,51-81,25 yang berada pada mutu pelayanan B (baik).
\end{abstract}

\section{ABSTRACT}

Arminsyah, Merri Anitasari; An Analysis Of Services Quality at Drinking Water Company (PDAM) Tirta Alami Kepahiang. This research aims to investigate the quality of Services at drinking water Company (PDAM) Natural Tirta Kepahiang. This research then used questionnaire as the data collecting method. Quantitative analysis then also be used as a techniques for data analysis by using weighted average value formula formed by Men Pan decree Number $K E P / 25 / m$. PAN/2/2004 on the 14 items that are observed. From the questionnaire it was obtained that the highest average of services is on the ease of servicing requirements with a value of 3.03. While the lowest average value of service is on the services equity which gain a score 2.95. For IKM value, it get 63 which places between 62.51-81.25. This score means that the performance of PDAM Tirta Alami Kepahiang is good.

\section{Kata kunci: Kualitas Pelayanan}

\section{PENDAHULUAN}

Badan Usaha Milik Daerah (BUMD) yaitu Perusahaan Daerah Air Minum Tirta Alami Kabupaten Kepahiang yang merupakan perusahaan yang bergerak dalam bidang penjualan air bersih dan memproduksikan air minum. Untuk meningkatkan tingkat kualitas pelayanan kepada pelanggan. Dalam hal 
menggunakan pelayanan air bersih yaitu pemasangan sambungan baru dengan kredit maupun tunai.

Perusahaan Daerah Air Minum Tirta Alami Kabupaten Kepahiang dalam memberikan pelayanan terhadap penggunaan air minum ada beberapa pelayanan yang kurang memuaskan pelanggan. Hal ini berdasarkan pra penelitian dari 10 orang pelanggan PDAM Tirta Alami Kabupaten Kepahiang. Dari 10 pelanggan, 7 orang pelanggan yang menyatakan kurang puas terhadap pelayanan yang diberikan oleh Perusahaan Daerah Air Minum Tirta Alami Kabupaten Kepahiang. Salah satu ukuran tingkat kualitas pelayanan adalah dapat memberikan kepuasan kepada pelanggan menggunakan jasa. Kepuasan pelanggan adalah tingkat perasaan yang merupakan hasil kinerja yang dirasakan dengan harapan. Harapan perasaan yang senang oleh pelanggan diperoleh jika kinerja pelayanan yang diberikan kepada pelanggan melebihi harapan. Jika kinerja pelayanan dibawah harapan atau tidak memenuhi harapan, maka perasaan senang yang dimiliki pelanggan akan merasa kurang puas dan dirugikan.

Untuk meningkatkan tingkat kualitas pelayanan Perusahaan Daerah Air Minum Tirta Alami Kabupaten Kepahiang membuka sarana dan tempat pengaduan agar para pelanggan dapat mengajukan komplin bila terjadi gangguan terhadap penggunaan air minum. Perusahaan Daerah Air Minum Tirta Alami Kabupaten Kepahiang dalam statistik hubungan tingkat pelayanan terhadap kepuasan pelanggan menunjukkan bahwa sering terjadi permasalahan pada pelayanan pembaca meter, gangguan terhadap pipa air, mutu air dan keterlambatan pelayanan tagihan rekening air.

Masalah pelayanan memiliki peran penting yang besar karena menyangkut kepentingan umum atau kepentingan masyarakat umum. Tujuan dari pelayanan itu sendiri adalah untuk memuaskan keinginan masyarakat pada umumnya, untuk mencapai kepuasan pelanggan maka harus adanya tingkat kualitas pelayanan yang sesuai dengan kebutuhan dan keinginan masyarakat atau pelanggan.

Dalam hal ini mengindentifikasi bahwa kurangnya kualitas tingkat pelayanan kepuasan pelanggan pada Perusahaan Daerah Air Minum Tirta Alami Kabupaten Kepahiang, mungkin disebabkan karyawan bagian pelayanan yang kurang mampu memberikan pelayanan yang baik, kurang tanggap kebutuhan pelanggan, jaminan yang diberikan kepada pelanggan kurang baik dan perhatian karyawan terhadap pelanggan secara individu masih kurang serta sarana sebagai pendukung pelayanan juga masih kurang.

\section{TINJAUAN LITERATUR Manajemen Pemasaran}

Pemasaran umumnya dipandang sebagai tugas untuk menciptakan, memperkenalkan dan menyerahkan barang dan jasa kepada konsumen. Pemasaran merupakan salah satu dari kegiatan-kegiatan pokok yang dilakukan oleh para pengusaha dalam usahanya untuk mempertahankan kelangsungan hidupnya, untuk berkembang dan mendapatkan laba. Berhasil tidaknya dalam pencapaian tujuan bisnis tergantung pada keahlian mereka dibidang pemasaran, produksi, keuangan maupun bidang lain. Selain itu juga tergantung pada kemampuan mereka untuk mengkombinasikan fungsi-fungsi tersebut agar organisasi dapat berjalan lancar.

Menurut Kotler dan Keller (2007:6), manajemen pemasaran adalah seni dan ilmu memilih pasar sasaran dan mendapatkan, menjaga dan menumbuhkan pelanggan dengan menciptakan, menyerahkan dan mengkomunikasikan nilai pelanggan yang unggul". 
Definisi ini mengakui bahwa manajemen pemasaran adalah proses yang melibatkan, analisa perencanaan, pelaksanaan dan pengendalian yang mencakup barang dan jasa dan gagasan yang tergantung pada pertukaran dan dengan tujuan menghasilkan kepuasan bagi pihak-pihak yang terlibat.

Dalam masyarakat terdapat berbagai macam kelompok yang ingin memenuhi kebutuhannya untuk maksud tersebut, mereka harus melakukan suatu usaha, sehingga satu dengan yang lainnya saling melayani. Kotler dalam swasta (2002:5) mengemukakan definisi pemasaran sebagai berikut : "Pemasaran adalah kegiatan manusia yang diarahkan pada usaha untuk memuaskan keinginan dan kebutuhan melalui proses pertukaran".

Menurut definisi tersebut, mula-mula manusia harus menemukan kebutuhannya dulu, baru kemudian berusaha untuk memenuhinya dengan cara mengadakan hubungan. Dapat pula dikatakan bahwa kegiatan pemasaran itu diciptakan oleh pembeli dan penjual. Kedua belak pihak sama-sama ingin mencari kepuasan. Dalam hal ini, pembeli berusaha memenuhi kebutuhannya, sedangkan penjual berusaha mendapatkan laba. Kedua macam kepentingan ini dapat dipertemukan dengan cara mengadakan pertukaran yang saling mengutungkan.

Pemasaran secara esensial adalah proses kreatif yang memiliki dasar ilmiah tetapi tidak ada jaminan mutlak untuk kesuksesan. Pemasaran yang efektif mengurangi resiko kegagalan dan bahkan jika kita bersikap positif meningkatkan kemungkinan untuk meraih sukses. Satu hal yang tetap adalah bahwa pelanggan akan terus menuntut, berubah-ubah dan tidak dapat ditebak, sehingga pemasaran betapapun efektifnya selalu membawa unsur resiko. Pemasaran adalah pusat dari keseluruhan pikiran keberadaan suatu organisasi dan hubungannya dengan pasar dan pelanggannya.

Menurut Kotler dalam Swasta (2007:7) mendefinisikan manajemen pemasaran sebagai berikut "Penganalisaan, perencanaan, pelaksanaan dan pengawasan program-program yang ditujukan untuk mengadakan pertukaran dengan pasar yang dituju dengan maksud untuk mencapai tujuan organisasi. Hal ini sangat tergantung pada penawaran organisasi dalam memenuhi kebutuhan dan keinginan pasar tersebut serta menentukan harga, mengadakan komunikasi, distribusi yang efektif yang memberitahu, mendorong serta melayani pasar".

Dalam fungsi manajemen tersebut termasuk penganalisaan, perencanaan, pelaksanaan dan penerapan serta pengawasannya. Tahap perencanaan, khususnya merupakan tahap yang sangat menentukan terhadap kelangsungan dan sukses organisasi. Proses perencanaan merupakan satu proses yang selalu memandang kedepan atau kemungkinan-kemungkinan yang akan datang termasuk disini adalah perkembangan program, kebijaksanaan d an prosedur untuk mencapai tujuan-tujuan pemasaran.

Untuk membuat suatu rencana, fungsi penganalisaan sangat penting agar rencana yang dibuat dapat lebih matang dan tepat. Dari segi lain penerapan merupakan kegiatan untuk menjalankan rencana, sedangkan fungsi terakhir dari manajemen adalah pengawasan yaitu fungsi pengendalian ini untuk menghindari adanya penyimpangan atau memperkecil penyimpangan yang mungkin terjadi.

Pemasaran adalah proses social dan manajerial yang didalam individu dan kelompok mendapatkan apa yang mereka butuhkan dan inginkan dengan menciptakan, menawarkan dan mempertukarkan produk yang bernilai dengan pihak lain (Kotler, 2003:8).

Dari definisi tersebut artinya kita meninjau pemasaran sebagai suatu sistem dari kegiatan-kegiatan yang saling berhubungan, ditujukan untuk merencanakan, menentukan harga, mempromosikan dan mendistribusikan barang dan jasa kepada kelompok pembeli.

Kegiatan-kegiatan tersebut beroperasi suatu lingkungan yang dibatasi oleh sumber-sumber dari perusahaan itu sendiri, peraturan-peraturan maupun 
konsekuensi social perusahaan. Pada umumnya, dalam pemasaran perusahaan berusaha menghasilkan laba dari penjualan barang dan jasa yang diciptakan untuk memenuhi kebutuhan pembeli. Namun demikian, pemasaran juga dilakukan untuk mengembangkan, mempromosikan dan mendistribusikan program-program dan jasa yang disponsori oleh organisasi non laba. Jadi, tugas manajer pemasaran adalah memilih dan melaksanakan kegiatan pemasaran yang dapat membantu dalam pencapaian tujuan organisasi.

\section{Jasa}

Menurut Bruce J Walker dalam Djaslim Salidin (1996:6) Jasa adalah “Kegiatan yang dapat didefinisikan yang tidak terwujud yang merupakan tujuan penting dari suatu rencana transaksi guna memberikan kepuasan konsumen".

Menurut Kotler dalam Fandi Tjuptono (2004:6) Jasa adalah "Setiap tindakan atau perbuatan yang dapat ditawarkan oleh suatu pihak kepada pihak lain yang pada dasarnya bersifat imtangible (tidak berwujud fisik) dan tidak menghasilkan kepemilikan suatu produksi jasa biasa berhubungan dengan fisik maupun tidak".

Salah satu bentuk rasa dari jasa adalah kepuasan. Sedangkan karakteristik jasa menurut Kotler (2003:84) adalah :

1. Tidak berwujud, yaitu tidak dapat dilihat, diraba, dibaui ataupun didengar sebelum jasa tersebut dibeli.

2. Tidak dapat dipisahkan, yaitu pada umumnya jasa diproduksi dan dirasakan pada waktu bersamaan dan apabila dikehendaki oleh seseorang untuk diserahkan pada orang lain maka ia akan tetap merupakan bagian dari jasa tersebut. Jasa tidak dapat dipisahkan baik oleh orang, dengan mesin atau kedua-duanya. Jasa tertentu harus diciptakan dan digunakan pada saat bersamaan.

3. Berubah-ubah, yaitu sangat mudah berubah karena jasa ini sangat tergantung pada siapa yang menyajikan, kapan dan dimana saja jasa tersebut dibutuhkan.

4. Cepat hilang, yaitu jasa tidak dapat dismpan lama dan permintaannya sangat berfluktuasi.

Dari definisi di atas dapat disimpulkan bahwa pengertian jasa adalah suatu kegiatan yang dapat didefinisikan dan tidak berwujud yang ditawarkan oleh suatu pihak kepada pihak lain, tidak menghasilkan kepemilikan sesuatu dengan tujuan untuk memberikan kepuasan kepada pelanggan atau konsumen dan memperoleh hasil pendapatan.

\section{Unsur Pelayanan}

Menurut Keputusan Menteri Pendayagunaan Aparatur Negara Nomor : KEP/25/M.PAN/2/2004 tentang Pedoman Umum Penyusunan Indeks Kepuasan Masyarakat Unit Pelayanan Instansi Pemerintah, unsur kepuasan pelayanan masyarakat terdiri dari 14 unsur :

1. Prosedur pelayanan, yaitu kemudahan tahapan pelayanan yang diberikan kepada masyarakat dilihat dari sisi kesederhanaan alur pelayanan.

2. Persyaratan pelayanan, yaitu persyaratan teknis dan administrasi yang diperlukan untuk mendapatkan pelayanan sesuai dengan jenis pelayanannya.

3. Kejelasan petugas pelayanan, keberadaan dan kepastian petugas yang memberikan pelayanan (nama, jabatan serta kewenangan dan tanggung jawabnya).

4. Kedisplinan petugas pelayanan, yaitu kesungguhan petugas dalam memberikan pelayanan terutama terhadap konsistensi waktu kerja sesuai dengan ketentuan yang berlaku. 
5. Tanggung jawab petugas pelayanan, yaitu kejelasan wewenang dan tanggung jawab petugas dalam penyelenggaraan dan penyelesaian pelayanan.

6. Kemampuan petugas pelayanan, yaitu tingkat keahlian dan keterampilan yang dimiliki petugas dalam memberikan/menyelesaikan pelayanan kepada masyarakat

7. Kecepatan pelayanan, yaitu target waktu pelayanan dapat diselesaikan dalam waktu yang telah ditentukan oleh unit penyelenggara pelayanan.

8. Keadilan mendapatkan pelayanan, yaitu pelaksanaan pelayanan dengan tidak membedakan golongan/status masyarakat yang dilayani.

9. Kesopanan dan keramahan petugas, yaitu sikap dan perilaku petugas dalam memberikan pelayanan kepada masyarakat secara sopan dan ramah serta saling menghargai dan menghormati.

10. Kewajaran biaya pelayanan, yaitu keterjangkauan masyarakat terhadap besarnya biaya yang ditetapkan oleh unit pelayanan.

11. Kepastian biaya pelayanan, yaitu kesesuaian antara biaya yang dibayarkan dengan biaya yang telah ditetapkan.

12. Kepastian jadwal pelayanan, yaitu pelaksanaan waktu pelayanan sesuai dengan ketentuan yang telah ditetapkan.

13. Kenyamanan lingkungan, yaitu kondisi sarana dan prasarana pelayanan yang bersih, rapid an teratur sehingga dapat memberikan rasa nyaman kepada penerima pelayanan.

14. Keamanan pelayanan, yaitu terjaminnya tingkat keamanan lingkungan unit penyelenggara pelayanan ataupun sarana yang digunakan, sehingga masyarakat merasa tenang untuk mendapatkan pelayanan terhadap resiko-resiko yang diakibatkan dari pelaksanaan.

\section{Pelayanan}

Pelayanan adalah merupakan suatu tindakan atau perbuatan seseorang atau organisasi untuk memberikan kepuasan kepada pelanggannya atau konsumennya (Kasmir, 2005:26). Secara umum pelayanan dapat diartikan dengan melakukan kegiatan atau perbuatan yang hasilnya ditujukan untuk kepentingan orang lain, baik perorangan, kelompok atau masyarakat. Pelayanan timbul karena adanya kewajiban sebagai suatu penyelenggaraan kegiatan organisasi baik organisasi pemerintah maupun organisasi swasta.

Pelayanan umum muncul karena adanya kepentingan umum. Pelayanan umum bukanlah tujuan, melainkan suatu proses untuk mencapai sasaran tertentu yang telah ditetapkan. Pelayanan berperan sebagai katalisator yang mempercepat proses sesuai dengan apa seharusnya. Proses pemenuhan kebutuhan melalui aktivitas orang lain inilah yang dinamakan pelayanan. Pengertian proses dalam konteks ini terbatas pada kegiatan manajemen dalam rangka pencapaian tujuan organisasi. Jadi pelayanan yang dimaksud adalah pelayanan dalam rangkaian organisasi dan manajemen pelayanan.

Pelayanan umum berdaya guna adalah pelayanan yang member kepuasan kepada pelanggan. Tolak ukurnya adalah tidak ada atau kurangnya keluhan masyarakat pelanggan. Sedangkan pelayanan umum yang berhasil guna misalnya ditandai dengan tidak adanya ccalo-calo dalam pemberian pelayanan oleh perusahaan. Untuk meningkatkan pelayanan umum berdaya guna dan berhasil guna paling tidak pemberi layanan harus selalu berupaya memperbaiki hal-hal yang erat kaitannya dengan kegiatan pemberian pelayanan tersebut antara lain memperbaiki sistemnya dan terbuka terhadap masyarakat.

Selain pelayanan umum berhasil guna dan berdaya guna dikenal pula pelayanan berkualitas. Yang dimaksud dengan pelayanan berkualitas adalah 
layanan yang cepat, menyenangkan, tidak mengandung kesalahan, mengikuti proses dan prosedur yang telah ditetapkan lebih dahulu. Untuk mencapai pelayanan umum yang telah berhasil guna, berdaya guna dan berkualitas, maka perlu diterapkan prinsip-prinsip pelayanan sebagai berikut :

1. Proses dan prosedur harus ditetapkan lebih awal

2. Semua pihak harus mengetahui dan memahami proses dan prosedur

3. Disiplin bagi pelaksanaan untuk mentaati proses dan prosedur

4. Perlu peninjauan proses dan prosedur oleh pemimpin sewaktu-waktu dapat dirubah apabila perlu

5. Perlu penciptaan iklim yang kondusif bagi pengembangan budaya organisasi untuk penciptaan kualitas pelayanan

6. Kualitas berarti memenuhi keinginan, kebutuhan dan selera konsumen

7. Setiap orang dalam organisasi merupakan partner dengan orang lainnya

Menurut Moenir (2002:41) sebagai pihak yang ingin memperoleh pelayanan

yang baik dan memuaskan, maka perwujudan pelayanan yang memuaskan adalah :

1. Adanya kemudahan dalam pengurusan kepentingan dengan pelayanan yang cepat dalam arti tanpa hambatan yang kadang kala di buat-buat

2. Memperolah pelayanan secara wajar

3. Mendapatkan perlakuan yang sama dalam pelayanan terhadap kepentingan yang sama, tertib dan tidak pandang bulu.

4. Pelayanan yang jujur dan terus terang, artinya apabila ada hambatan karena suatu masalah yang tidak dapat dielakkan hendaknya diberitahukan, sehingga seseorang tidak menunggu sesuatu yang tidak menentu.

Menurut Kotler (2003:112) mengatakan bahwa pelayanan adalah suatu aktivitas yang memberikan manfaat dan ditawarkan oleh suatu pihak kepada pihak lain dalam bentuk tidak nyata (intangible) dan tidak menimbulkan pemindahan kepemilikannya. Pelayanan adalah semua aktivitas ekonomi yang hasilnya tidak merupakan produk dalam bentuk fisik atau konstruksi yang biasa dikonsumsi pada saat yang sama dengan waktu memproduksi sambil memberikan nilai tambah (seperti : kenyamanan, kesehatan, hiburan dan kesenangan).

Menurut Kasmir (2005:233) dalam praktiknya pelayanan yang baik memiliki ciri-ciri tersendiri dan hamper semua perusahaan menggunakan kriteria yang sama untuk membentuk ciri-ciri pelayanan yang baik tersebut. Adapun ciri-ciri pelayanan yang baik adalah sebagai berikut:

1. Tersedia personil yang baik

2. Tersedia sarana dan prasana yang baik

3. Bertanggung jawab kepada setiap pelanggan sejak awal hingga akhir

4. Mampu melayani secara cepat dan tepat

5. Mampu berkomunikasi

6. Memberikan jaminan kerahasiaan setiap transaksi

7. Memiliki pengetahuan dan kemampuan yang baik

8. Berusaha memahami kebutuhan pelanggan

9. Mampu memberikan kepercayaan kepada pelanggans

Menurut Gronroos dalam Ratminto (2005:2) pelayanan adalah suatu aktivitas atas serangkaian aktivitas yang bersifat tidak kasat mata yang terjadi sebagai akibat adanya interaksi antara konsumen dengan karyawan personel atau hal-hal lain yang disediakan oleh perusahaan pemberi layanan yang dimaksudkan untuk memecahkan permasalahan pelanggan.

Menurut Sutedja (2007:2) mengemukakan beberapa hak-hak konsumen atau pelanggan yang harus didapatkan dari suatu pelayanan perusahaan. Hal ini merupakan aspek-aspek yang ada dalam pelayanan pelanggan, jelas sekali bahwa aspek dalam pelayanan pelanggan merupakan suatu indicator baik 
buruknya suatu pelayanan pelanggan. Adapun hak-hak konsumen / pelanggan adalah:

1. Mereka berhak mendapatkan pelayananyang tepat waktu

2. Mereka berhak diperlakukan dengan sopan, jujur dan penuh hormat

3. Mereka berhak mendapatkan jawaban atas permintaan mereka dengan cepat dan pasti.

4. Mereka berhak melanjutkan pelayanan yang mampu memahami permintaannya

5. Mereka berhak mengetahui apa yang dikerjakan dengan permintaannya sampai dimana proses pengerjaan dan kapan akan selesai.

6. Mereka berhak diperlakukan sama seperti apa yang kita inginkan apabila kita menjadi pelanggan orang lain

7. Mereka berhak menerima jaminan kepuasan yang baik dari perugas pelayanan pelanggan

8. Mereka berhak mengeluhkan pelayanan yang buruk atau pelayanan yang tidak memuaskan kepada manajemen

\section{Kualitas Pelayanan}

Kualitas pelayanan adalah sebuah kata yang bagi penyaji jasa merupakan suatu yang harus dikerjakan dengan baik. Aplikasi dari sifat penampilan produk atau kinerja merupakan bagian utama dari strategi perusahaan dalam rangka mencari keunggulan yang berkesinambungan, baik sebagai pemimpin pasar ataupun sebagai strategi untuk terus tumbuh.

Kualitas pelayanan adalah suatu yang kompleks, oleh Fitzsimmons dalam Nuzuludin (2003:16) dijelaskan bahwa pelanggan menilai kualitas pelayanan dilihat dari lima dimensi sebagai berikut :

1. Kehandalan (reliability), yaitu kemampuan untuk memberikan pelayanan secara tepat dan cepat jenis pelayanan yang telah dijanjikan pada pelanggan.

2. Daya tanggap (responsive), yaitu suatu kesadaran atau keinginan untuk cepat bertindak (respon) membantu pelanggan setiap permasalahan dan keluhan pelanggan secara disikapi dengan cepat.

3. Jaminan (assurance), yaitu kemampuan para pegawai untuk menambah rasa percaya para pelanggan kepada perusahaan.

4. Empati (emphaty), yaitu perusahaan memberikan perhatian dan kepedulian terhadap pelanggan secara individual dan berupaya memahami keinginannya.

5. Berwujud (tangible), yaitu sesuatu yang tampak atau nyata, misalnya penampilan karyawan dan prasarana fisik, seperti peralatan dan perlengkapan yang menunjang pelaksanaan pelayanan.

Untuk menciptakan kualitas pelayanan yang tinggi menurut Tiptono (2000:99) bahwa secara garis besar strategi pemasaran jasa yang pokok berkaitan dengan :

1. People, yaitu orang yang dilatih agar dapat diandalkan.

2. Phisycal Environment, yaitu lingkungan yang dikembangkan

3. Procces, yaitu proses penyampaian pelayanan yang dirancang dengan lebih superior

Dalam memberikan pelayanan harus memperhatikan bagaimana pelayanan yang ditujukan pada masyarakat, apakah telah sesuai dengan harapan pelanggan atau belum. Karena pelanggan sangat dipengaruhi oleh pelayanan yang diberikan perusahaan.

\section{Kerangka Analisis}

14 Unsur Pelayanan 


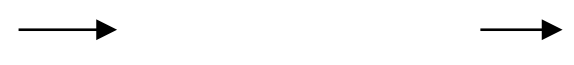

Gambar 1. Kerangka Analisis

\section{HASIL PENELITIAN DAN PEMBAHASAN Karakteristik Responden}

Dalam penelitian ini penulis melakukan penyebaran kuisioner hanya kepada 150 orang responden. Berdasarkan penyebaran kuisioner dengan 150 orang responden, diperoleh karakteristik responden sebagai berikut:

\section{Jumlah Responden Berdasarkan Jenis Kelamin}

Dari penyebaran kuisioner maka dapat diketahui jumlah responden berdasarkan jenis kelamin, dapat dilihat pada tabel berikut:

\section{Tabel 1. Jumlah Responden Berdasarkan Jenis Kelamin}

\begin{tabular}{|l|l|l|}
\hline Jenis Kelamin & Jumlah (orang) & Persentase (\%) \\
\hline Laki-laki & 120 & 80 \\
Perempuan & 30 & 20 \\
\hline Jumlah & $\mathbf{1 5 0}$ & $\mathbf{1 0 0}$ \\
\hline
\end{tabular}

Sumber: Data diolah tahun 2012

Dari tabel tersebut di atas, maka dapat diketahui jumlah responden yang memiliki jenis kelamin laki-laki sebanyak 120 orang atau $80 \%$, sedangkan yang berjenis kelamin perempuan sebanyak 30 orang atau $30 \%$.

Dari penghitungan tersebut, maka diketahui bahwa jumlah pelanggan yang berjenis kelamin laki-laki lebih banyak dibanding dengan jumlah pelanggan yang berjenis kelamin perempuan. Hal ini dikarenakan kaum laki-laki lebih banyak bisa meluangkan waktu untuk keluar rumah guna membayar rekening air dibandingkan dengan perempuan yang pada umumnya sibuk mengurus pekerjaan rumah tangga dan anak.

\section{Jumlah responden berdasarkan usia}

Dari penyebaran kuisioner maka dapat diketahui jumlah responden berdasarkan jenis kelamin, dapat dilihat pada tabel berikut:

\section{Tabel 2. Jumlah Responden Berdasarkan Usia}

\begin{tabular}{|c|c|c|}
\hline Usia & Jumlah (orang) & Persentase (\%) \\
\hline$<25$ tahun & 16 & 10 \\
\hline 26-35 tahun & 40 & 27 \\
\hline 36-45 tahun & 55 & 37 \\
\hline$>45$ tahun & 39 & 26 \\
\hline Jumlah & 150 & 100 \\
\hline
\end{tabular}

Sumber: Data diolah tahun 2012

Dari tabel 2. tersebut di atas, maka dapat diketahui jumlah responden yang memiliki usia kurang dari 25 tahun sebanyak 16 orang atau 10\%, jumlah responden yang memiliki usia 26 tahun sampai dengan 35 tahun tahun sebanyak 40 orang atau $27 \%$, jumlah responden yang memiliki usia 36 tahun sampai dengan 45 tahun sebanyak 55 orang atau $37 \%$, sedangkan jumlah responden yang memiliki usia lebih dari 45 tahun sebanyak 39 orang atau $26 \%$. 
Dari penghitungan tersebut, maka diketahui bahwa jumlah pelanggan yang berusia 36 tahun sampai dengan 45 tahun lebih banyak dibandingkan dengan jumlah pelanggan yang berusia selain dari usia tersebut. Hal ini dikarenakan usia antara 36 tahun sampai dengan 45 tahun lebih banyak keluar rumah guna membayar rekening air. Hal ini dikarenakan waktu mereka bekerja di kantor, lapangan, pasar, dan lain sebagainya sekaligus mereka gunakan untuk membayar rekening air.

\section{Jumlah Responden Berdasarkan Tingkat Pendidikan}

Dari penyebaran kuisioner maka dapat diketahui jumlah responden berdasarkan tingkat pendidikan, dapat dilihat pada tabel berikut:

Tabel 3. Jumlah Responden Berdasarkan Tingkat Pendidikan
\begin{tabular}{|l|c|c|}
\hline Tingkat Pendidikan & Jumlah (orang) & Persentase (\%) \\
\hline SD Ke bawah & 8 & 6 \\
SMP & 15 & 10 \\
SLTA & 55 & 36 \\
Diploma & 12 & 8 \\
S.1 & 60 & 40 \\
\hline \multicolumn{1}{|c|}{ Jumlah } & $\mathbf{1 5 0}$ & $\mathbf{1 0}$ \\
\hline
\end{tabular}

Sumber: Data diolah tahun 2012

Dari tabel 3. di atas, maka dapat diketahui jumlah responden yang paling sedikit adalah responden yang berpendidikan SD ke bawah, hanya 8 orang atau $6 \%$ dari 150 orang responden. Hal ini dikarenakan wawasan responden dalam memanfaatkan fasilitas yang ada di daerah sangat kurang. Sedangkan jumlah responden yang paling bannyak adalah responden dengan tingkat pendidikan sarjana (S.1) yaitu sebanyak 60 orang atau 40\%. Hal ini menggambarkan bahwa jumlah pelanggan yang berpendidikan tinggilah yang banyak menggunakan jasa PDAM Tirta Alami di Kabupaten Kepahiang.

\section{Jumlah Responden Berdasarkan Pekerjaan}

Dari penyebaran kuisioner maka dapat diketahui jumlah responden berdasarkan pekerjaan, dapat dilihat pada tabel berikut:

\section{Tabel 4. Jumlah Responden Berdasarkan Pekerjaan}

\begin{tabular}{|l|c|c|}
\hline \multicolumn{1}{|c|}{ Pekerjaan } & Jumlah (orang) & Persentase (\%) \\
\hline Tani & 100 & 66 \\
Karyawan Swasta & 25 & 17 \\
PNS/Polri/TNI & 15 & 10 \\
Pelajar/Mahasiswa & 2 & 1 \\
Lainnya Jumlah & 8 & 6 \\
\hline \multicolumn{2}{|c|}{ Jum } \\
\hline
\end{tabular}

Sumber: Data diolah tahun 2012

Dari tabel 4. di atas, maka dapat diketahui jumlah responden yang memiliki pekerjaan sebagai petani sebanyak 100 orang atau 66\%, jumlah ini merupakan responden yang paling banyak dari jumlah keseluruhan responden. Jumlah responden yang memiliki pekerjaan sebagai karyawan swasta sebanyak 25 orang atau $17 \%$, jumlah responden yang memiliki pekerjaan sebagai PNS/Polri/TNI sebanyak 15 orang atau 10\%, jumlah responden yang memiliki pekerjaan sebagai pelajar/mahasiswa sebanyak 2 orang atau 1\%, jumlah ini 
menunjukkan bahwa pelanggan PDAM Tirta Alami Kabupaten Kepahiang yang paling sedikit adalah pelajar/mahasiswa, hal ini dikarenakan plajar/mahasiswa masih ikut orang tua atau belum mandiri. Jumlah responden yang memiliki pekerjaan selain dari pekerjaan yang disebutkan di atas sebanyak 8 orang atau $6 \%$.

\section{Nilai Indeks Kepuasan Masyarakat}

Berdasarkan data dari lampiran 1 dapat diketahui nilai rata-rata per unsur layanan sesuai dengan ketentuan Men.Pan No. KEP/25/M.PAN/2/2004 dengan rumus sebagai berikut:

Nilai Rata-rata Per Unsur Layanan $=\frac{\text { Nilai Unsur Layanan }}{\text { Jumlah Pelanggan }}$

Hasil penghitungan keseluruhan dari masing-masing rata-rata per unsur layanan dapat dilihat pada table berikut.

\section{Tabel 5. Nilai Unsur Per Layanan}

\begin{tabular}{|c|c|c|c|c|}
\hline $\begin{array}{l}\mathbf{N} \\
\mathbf{0}\end{array}$ & Unsur Pelayanan & $\begin{array}{c}\text { Nilai } \\
\text { Unsur } \\
\text { Pelayana } \\
\text { n (a) }\end{array}$ & $\begin{array}{l}\text { Jumlah } \\
\text { Responde } \\
\text { n (b) }\end{array}$ & $\begin{array}{c}\text { Nilai Rata-rata } \\
\text { Per Unsur } \\
\text { Pelayanan } \\
\text { (c = a/b) }\end{array}$ \\
\hline 1 & Prosedur Pelayanan & 451 & 150 & 3,01 \\
\hline 2 & Persyaratan Pelayanan & 454 & 150 & 3,03 \\
\hline 3 & $\begin{array}{ll}\text { Kejelasan } & \text { Petugas } \\
\text { Pelayanan } & \\
\end{array}$ & 446 & 150 & 2,98 \\
\hline 4 & $\begin{array}{ll}\text { Kedisiplinan } & \text { Petugas } \\
\text { Pelayanan } & \\
\end{array}$ & 453 & 150 & 3,02 \\
\hline 5 & $\begin{array}{l}\text { Tanggung Jawab Petugas } \\
\text { Pelayanan }\end{array}$ & 445 & 150 & 2,97 \\
\hline 6 & $\begin{array}{ll}\text { Kemampuan } & \text { Petugas } \\
\text { Pelayanan } & \\
\end{array}$ & 443 & 150 & 2,96 \\
\hline 7 & Kecepatan Pelayanan & 451 & 150 & 3,01 \\
\hline 8 & $\begin{array}{ll}\text { Keadilan } & \text { Mendapatkan } \\
\text { Pelayanan } & \\
\end{array}$ & 442 & 150 & 2,95 \\
\hline 9 & $\begin{array}{l}\text { Kesopanan dan Keramahan } \\
\text { Petugas }\end{array}$ & 447 & 150 & 2,98 \\
\hline 10 & Kewajaran Biaya & 452 & 150 & 3,02 \\
\hline 11 & Kepastian Biaya & 453 & 150 & 3,02 \\
\hline 12 & Kepastian Jadwal & 446 & 150 & 2,98 \\
\hline 13 & Kenyamanan Lingkungan & 448 & 150 & 2,99 \\
\hline 14 & Keamanan dan Pelayanan & 445 & 150 & 2,97 \\
\hline
\end{tabular}

Sumber : Hasil Penelitian, Data diolah tahun 2012

Berdasarkan tabel 5. di atas, maka dapat dilihat bahwa nilai rata-rata per unsur pelayanan yang paling tinggi adalah pada pemahaman pelanggan tentang kemudahan persyaratan pelayanan yang diberikan oleh PDAM Tirta Alami yaitu dengan nilai unsur 3,03. Hal ini menunjukkan bahwa pelanggan mendapatkan kemudahan dalam persyaratan pelayanan yang diberikan selama ini oleh PDAM Tirta Alami Kabupaten Kepahiang.

Sedangkan nilai rata-rata per unsur pelayanan yang paling rendah yaitu pada keadilan mendapatkan pelayanan sebesar 2,95. Hal ini berarti masih banyak para pelanggan beranggapan bahwa keadilan dalam pelayanan yang diterapkan oleh PDAM Tirta Alami masih lemah. 
Untuk mencari nilai rata-rata tertimbang per unsur pelayanan, maka jumlah nilai rata-rata per unsur pelayanan dikalikan dengan 0,071 (sesuai dengan ketentuan Men.Pan Nomor KEP/25/M.PAN/2/2004) sebagai nilai bobot rata-rata tertimbang. Perhitungan tersebut dapat dilihat pada tabel berikut:

Tabel 6. Nilai Rata-rata Tetimbang Per Unsur Layanan

\begin{tabular}{|c|c|c|c|c|}
\hline No & Unsur Pelayanan & $\begin{array}{c}\text { Rata-rata } \\
\text { Nilai Per } \\
\text { Pelayanan } \\
\text { (a) }\end{array}$ & $\begin{array}{c}\text { Nilai } \\
\text { Bobot } \\
\text { Tertimban } \\
\text { g (b) }\end{array}$ & $\begin{array}{l}\text { Nilai Rata- } \\
\text { rata } \\
\text { Tetimbang } \\
(\mathbf{c}=\mathbf{a x b})\end{array}$ \\
\hline 1 & Prosedur Pelayanan & 3,01 & 0,071 & 0,21 \\
\hline 2 & Persyaratan Pelayanan & 3,03 & 0,071 & 0,22 \\
\hline 3 & $\begin{array}{l}\text { Kejelasan Petugas } \\
\text { Pelayanan }\end{array}$ & 2,98 & 0,071 & 0,21 \\
\hline 4 & $\begin{array}{l}\text { Kedisiplinan Petugas } \\
\text { Pelayanan }\end{array}$ & 3,02 & 0,071 & 0,21 \\
\hline 5 & $\begin{array}{l}\text { Tanggung Jawab Petugas } \\
\text { Pelayanan }\end{array}$ & 2,97 & 0,071 & 0,21 \\
\hline 6 & $\begin{array}{l}\text { Kemampuan Petugas } \\
\text { Pelayanan }\end{array}$ & 2,96 & 0,071 & 0,21 \\
\hline 7 & Kecepatan Pelayanan & 3,01 & 0,071 & 0,21 \\
\hline 8 & $\begin{array}{l}\text { Keadilan Mendapatkan } \\
\text { Pelayanan }\end{array}$ & 2,95 & 0,071 & 0,20 \\
\hline 9 & $\begin{array}{l}\text { Kesopanan dan Keramahan } \\
\text { Petugas }\end{array}$ & 2,98 & 0,071 & 0,21 \\
\hline 10 & Kewajaran Biaya & 3,02 & 0,071 & 0,21 \\
\hline 11 & Kepastian Biaya & 3,02 & 0,071 & 0,21 \\
\hline 12 & Kepastian Jadwal & 2,98 & 0,071 & 0,21 \\
\hline 13 & Kenyamanan Lingkungan & 2,99 & 0,071 & 0,21 \\
\hline 14 & Keamanan dan Pelayanan & 2,97 & 0,071 & 0,21 \\
\hline
\end{tabular}

Sumber : Hasil Penelitian, Data diolah tahun 2012

Dari tabel di atas, maka dapat dilihat bahwa nilai rata-rata persyaratan pelayanan memiliki nilai tertinggi yaitu 3,03. Nilai tersebut berada diantara 2,51 - 3,25 yang berada pada mutu pelayanan baik. Hal ini menunjukkan bahwa persyaratan pelayanan pada PDAM Tirta Alami dinilai baik oleh pelanggan karena PDAM Tirta Alami Kabupaten Kepahiang tidak mempersulit para pelanggan baik untuk pendaftaran, pembayaran maupun dalam prosedur pengaduan pada saat terjadi kerusakan serta penyelesaian permasalahan yang dihadapi pelanggan tidak memakan waktu yang lama dalam penyelesaiannya. Begitupun dengan nilai rata-rata tertimbang untuk unsur pelayanan pada persyaratan pelayanan memiliki nilai tertinggi yaitu 0,22 , sedangkan nilai terendah 0,20 terdapat di unsur pelayanan pada keadilan mendapatkan pelayanan, dan 12 unsur pelayanan yang lain memiliki nilai yang sama yaitu sebesar 0,21 .

Untuk mendapatkan nilai indeks kepuasan masyarakat terlebih dahulu dicari nilai indeks unit pelayanan yaitu nilai rata-rata tertimbang dari 14 unsur pelayanan dijumlahkan. Setelah itu dikalikan dengan nilai dasar yaitu 25.

Sesuai dengan ketentuan Men.Pan Nomor KEP/25/M.PAN/2/2004 bahwa nilai indeks unit pelayanan tersebut dikalikan dengan nilai dasar sebesar 25 sehingga didapat indeks kepuasan masyarakat yaitu:

$\mathrm{IKM}=\mathrm{IM}$ Unit Pelayanan $\times$ Nilai Dasar

$$
\begin{aligned}
& =2,94 \times 25 \\
& =73,5
\end{aligned}
$$


Dari perhitungan tersebut maka diketahui bahwa nilai IKM pada PDAM Tirta Alami Kabupaten Kepahiang sebesar 73,5. Hal ini menunjukkan bahwa kinerja unit pelayanan pada PDAM Tirta Alami Kabupaten Kepahiang "baik" karena nilai tersebut berada diantara 62,51-81,25 yang berada pada mutu pelayanan B (baik).

\section{Pembahasan}

Berdasarkan hal di atas maka dapat disimpulkan bahwa dari penyebaran kuesioner yang diberikan kepada 150 orang pelanggan PDAM Tirta Alami Kabupaten Kepahiang mempunyai pendapat bahwa pelayanan yang diberikan oleh PDAM Tirta Alami Kabupaten Kepahiang baik, yang bisa dilihat dalam 14 unsur pelayanan yang tertuang dalam kuesioner. Dari 14 unsur pelayanan tersebut, nilai terendah 0,20 terdapat di unsur pelayanan pada keadilan mendapatkan pelayanan. Hal ini berarti pelanggan menilai bahwa PDAM Tirta Alami Kabupaten Kepahiang masih kurang memberikan keadilan pada pelanggan dalam memberikan pelayanan walaupun prosedur pelayanan dan persyaratan pelayanan yang diberikan kepada para pelanggan PDAM Tirta Alami Kabupaten Kepahiang tidak mempersulit para pelanggan baik untuk pendaftaran, pembayaran maupun dalam prosedur pengaduan pada saat terjadi kerusakan serta penyelesaian permasalahan yang dihadapi pelanggan tidak memakan waktu yang lama dalam penyelesaiannya.

Para petugas pelayanan mempunyai kejelasan, bukanlah sembarang orang melainkan petugas yang telah mengikuti pelatihan dan pembekalan serta memiliki keterampilan yang diberikan oleh PDAM Tirta Alami Kabupaten Kepahiang sehingga kedisiplinan dan kemampuan dalam memberikan pelayanan kepada para pelanggan bisa dilakukan dengan baik.

Dalam melakukan pelayanan para petugas harus mempunyai tanggung jawab, tidak membedakan antara pelanggan yang satu dengan yang lain serta pelayanan yang diberikan cepat. Untuk melakukan hal tersebut kesopanan dan keramahan para petugas sangatlah pentingkarena PDAM merupakan perusahaan yang melakukan pelayanan jasa.

Berdasarkan penyebaran kuesioner tersebut, maka dapat diketahui pendapat para pelanggan bahwa selama ini PDAM Tirta Alami Kabupaten Kepahiang telah memberikan kewajaran dan kepastian dalam menetapkan harga sehingga menyebabkan para pelanggan merasa terjangkau dalam melakukan pembayaran.

Disamping itu kenyamanan lingkungan dan keamanan juga dinilai baik oleh pelanggan, hal ini ditunjang dengan adanya sarana dan prasarana yang mendukung yang dimiliki oleh PDAM Tirta Alami Kabupaten Kepahiang. Dengan demikian maka bisa dikatakan bahwa kualitas pelayanan jasa yang telah diberikan oleh PDAM Tirta Alami Kabupaten Kepahiang memang dalam keadaan baik. Dan untuk kedepan hendaknya PDAM Tirta Alami Kabupaten Kepahiang akan lebih memperhatikan dan meningkatkan pelayanannya sehingga menjadi sangat baik lagi.

\section{Kesimpulan}

Dari hasil penelitian dan analisis yang dilakukan, maka dapat ditarik kesimpulan bahwa:

1. Nilai rata-rata per unsur pelayanan yang paling tinggi adalah pada kemudahan persyaratan pelayanan yang diberikan oleh PDAM Tirta Alami Kabupaten Kepahiang yaitu dengan nilai unsur pelayanan sebesar 3,03 dan nilai rata-rata per unsur pelayanan yang paling rendah yaitu pada keadilan mendapatkan pelayanan sebesar 2,95. 
2. Nilai IKM pada PDAM Tirta Alami Kabupaten Kepahiang sebesar 73,5 yang berarti bahwa kinerja unit pelayanan pada PDAM Tirta Alami Kabupaten Kepahiang "baik" karena nilai tersebut berada diantara 62,51-81,25 yang berada pada mutu pelayanan B (baik).

\section{Saran}

Berdasarkan hasil penelitian yang telah dilakukan maka dapat diberikan beberapa saran yang bisa menjadi masukan untuk PDAM Tirta Alami Kabupaten Kepahiang:

1 Walaupun dari hasil penelitian menunjukkan bahwa IKM PDAM Tirta Alami Kabupaten Kepahiang 73,5 yang berarti bahwa kinerja unit pelayanan pada PDAM Tirta Alami Kabupaten Kepahiang "baik" karena nilai tersebut berada diantara 62,51-81,25 yang berada pada mutu pelayanan B (baik) bukan berarti PDAM Tirta Alami Kabupaten Kepahiang tidak memperhatikan unit-unit pelayanan yang telah diteliti. Namun sebaliknya akan lebih meningkatkan lagi unsur pelayanan yang telah diberikan sehingga bisa meningkatkan lagi mutu pelayanan pada nilai A "sangat baik".

2 Untuk menunjang hal tersebut sebaiknya PDAM Tirta Alami Kabupaten Kepahiang menambah lagi sarana dan prasarana yang belum ada guna kelancaran kegiatan pekerjaan para pegawai dalam menunjang pelayanan yang akan diberikan kepada pelanggan.

\section{DAFTAR PUSTAKA}

Brigita. 2011. Kualitas Jasa pada Perusahaan Daerah Air Minum (PDAM) Tirta Dharma Kota Bengkulu. Skripsi tidak diterbitkan. Bengkulu Program Studi Manajemen Fakultas Ekonomi Universitas Dehasen Bengkulu

Berdasarkan Keputusan Menteri Pendayagunaan Aparatur Negara Nomor: KEP/25/M.PAN/2/2004 tentang Pedoman Umum Penyusunan Indeks Kepuasan Masyarakat Unit Pelayanan Instansi Pemerintah

Kotler, Philip. 2003. Manajemen Pemasaran. Jakarta. Indeks

Kasmir, 2005. Manajemen Perbankan. Jakarta. PT. Raja Grafindo Pustaka

Moenir, H.A.S. 2005. Manajemen Pelayanan Umum di Indonesia. Jakarta. Bumi Aksa

Nuzulidin. 2003. Pengaruh Kualitas Pelayanan Terhadap Kepuasan Pelanggan. Pada Hotel Putra Bengkulu. FE. UNIB

Philip Kotler, Kevin Lane Keller. 2007. Manajemen Pemasaran Edisi 12. Jakarta. Indeks

Ratmito dan Atik Septi Winarsih. 2005. Manajemen Pelayanan. Yogyakarta. Pustaka Pelajar

Salidin. 1996. Dasar-Dasar Manajemen Pemasaran Bank. Jakarta. Maju Lancar

Sigaribuan, Masri dan Effendi Sopian. 1998. Metode Penelitian Survey. LP3ES. Jakarta

Sutedjo Wira. 2007. Panduan Pelayanan Konsumen. Jakarta. PT. Grasindo

Sugiyono. 2012. Metode Penelitian Bisnis. Alfabeta. Bandung

Swasta, Basu, dan Irawan. 2002. Manajemen Pemasaran. Jakarta. Erlangga

Tjiptono Fandy. 2004. Manajemen Jasa. Jakarta. Andi Offset 
Tjiptono Fandy. 2000. Strategi Pemasaran. Jakarta. Andi Offset

Widodo. 2012. Manajemen Kinerja. Raja Grafindo Persada. Jakarta 